\title{
Originalism, Federalism, and the American Constitutional Enterprise: A Historical Inquiry
}

Edward A. Purcell Jr.

New York Law School

Follow this and additional works at: http://digitalcommons.nyls.edu/fac_books

\section{Recommended Citation}

Purcell, Edward A. Jr., "Originalism, Federalism, and the American Constitutional Enterprise: A Historical Inquiry" (2007). Books. Book 2.

http://digitalcommons.nyls.edu/fac_books/2 


\section{ORIG INALISM, \\ FEDERALISM, AND}

\section{THE AMERICAN}

CONSTITUTIONAL

\section{ENTERPRISE}

A HISTORICAL INQUIRY

Edward A. Purcell Jr. 
Copyright (C) 2007 by Edward A. Purcell Jr. All rights reserved. This book may not be reproduced, in whole or in part, including illustrations, in any form (beyond that copying permitted by

Sections 107 and 108 of the U.S. Copyright Law and except by reviewers for the public press), without written permission from the publishers.

Set in Galliard and Copperplate types by The Composing Room of Michigan, Inc.

Printed in the United States of America.

Library of Congress Cataloging-in-Publication Data

Purcell, Edward A.

Originalism, federalism, and the American constitutional

enterprise : a historical inquiry / Edward A. Purcell, Jr.

$$
\text { p. } \mathrm{cm} \text {. }
$$

Includes bibliographical references and index.

ISBN 978-0-300-12203-9 (cloth : alk. paper) I. Federal

government-United States. 2. Constitutional history-United

States. 3. United States-Politics and government. I. Title.

$\mathrm{JK}_{325} \cdot \mathrm{P} 872007$

$320.473^{\prime} \mathrm{O} 49-\mathrm{dc} 22$

$200701235^{2}$

A catalogue record for this book is available from the British

Library.

The paper in this book meets the guidelines for permanence and durability of the Committee on Production Guidelines for Book Longevity of the Council on Library Resources.

$\begin{array}{llllllllll}0 & 9 & 8 & 7 & 6 & 5 & 4 & 3 & 2\end{array}$ 
CONTENTS

Acknowledgments ix

\section{INTRODUCTION. THE INQUIRY}

1 American Constitutional Federalism as a Normative Problem 3

\section{PART I. STRUCTURAL INTRINSICS}

2 Federalism as Doubly Blurred I7

3 Federalism as Fractionated 38

4 Federalism as Instrumental 53

5 Federalism as Contingent 69

\section{PART II. CONSEQUENTIAL DYNAMICS}

6 Kaleidoscopic Politics 85

7 Readjusting Components III

8 Contested Authorities 140

9 Evolving Understandings I6I 
PART III. CONCLUSION

10 The "Arduous Enterprise" I89 Notes 207

Index 293 


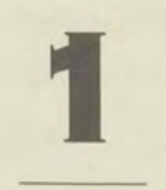

AMERICAN CONSTITUTIONAL FEDERALISM AS A NORMATIVE PROBLEM

As the twenty-first century began, two major and related developments seemed to be reshaping American constitutional law. One was the frequent invocation of theories of "originalism," claims that the Constitution should be interpreted in light of the "original" meaning it held for those who drafted and ratified it. ${ }^{1}$ The other was a "federalism revival," an intensifying effort to employ constitutional provisions to limit the powers of the national government and protect the sovereignty of the states. The two developments, moreover, seemed mutually supportive. The "original" relationship between nation and states - in contrast to the evolving series of relationships that developed over the subsequent centuries - had seen the national government exercising less extensive powers and the states holding sway over larger areas of American life. Thus, it was hardly surprising in the early twenty-first century that reinvigorated commitments to "originalism" and "federalism" might flourish in tandem.

Further, the growing popularity of originalism and federalism crossed political and ideological lines. Libertarians, economic "conservatives," and some other elements of the post-Reagan Republican coalition aggressively advanced both. ${ }^{2}$ Justice Antonin Scalia, for example, repeatedly stressed the importance of preserving state sovereign immunity ${ }^{3}$ and proclaimed that all constitutional decisions should be based on "the original meaning of the text." ${ }^{\prime 4}$ At the same time, many liberals, progressives, and moderates began climbing aboard the double-teamed bandwagon. In I999 President Bill Clinton issued an executive order that identified nine 
"Fundamental Federalism Principles" and directed federal officials to follow them in carefully scrutinizing actions that might cause "substantial direct effects on the States." He did so, the president announced, "to guarantee the division of governmental responsibilities between the national government and the States that was intended by the Framers of the Constitution." 5

In spite of such frequent invocations, both originalism and federalism raised the same fundamental and deeply troublesome question of constitutional law. To what extent was either capable of providing clear and authoritative constitutional norms? Could either, in truth, provide specific and determinative directions in resolving contested constitutional questions?

In helping to revive both originalism and federalism, the Rehnquist Court illustrated the extent to which the two ostensible norms provided uncertain and ambiguous directions. In the years after 1992 five of its justices began frequently to invoke "the essential principles of federalism" and the "original understanding of the Constitution" held by the "founding generation." ${ }^{\prime 6}$ When they did so, the Court immediately split, fragmenting badly in a train of important and potentially far-reaching decisions. Repeatedly, the other four justices dissented, often in sweeping and sometimes defiant terms. ${ }^{7}$ Indeed, after protesting a series of decisions that limited the power of Congress and expanded the sovereign immunity of the states, the four boldly announced their "continuing dissent" from the "aggressive" new federalism jurisprudence that made the Court "the champion of States' rights." 8 The dissenters, however, did not invariably agree among themselves and on occasion broke ranks on federalism issues. ${ }^{9}$ Far more striking and revealing, however, was the fact that the five justices in the "originalist" and "pro-federalism" majority also divided among themselves and did so with increasing frequency. ${ }^{10}$ In Idaho $v$. Coeur d'Alene Tribe of Idabo, for example, two of the five explained and applied their view of the "basic principles of federalism," 11 while the other three wrote separately to reject the analysis of the first two as "flawed in several respects." 12 Similarly, dealing with the scope of national power in another case, one of five chided the other four for not adopting "a standard more consistent with the original understanding." ${ }^{13}$ Indeed, in one recent decision four of the Rehnquist Court's five "pro-federalism" jus- tices voted to assert national authority and thereby limit state power, while the fifth joined the four so-called nationalist justices in limiting national authority and expanding state power. ${ }^{14}$

Such swings, divisions, and inconsistencies were hardly unprecedented. Over the decades, Americans had disagreed continuously and often passionately about the nature of their federal system. Their disagreements had begun at the Constitution's birth, moreover, and they were almost invariably rooted in conflicting visions of its "original" meaning.

It was true that when the Constitution was ratified, some of its provisions carried relatively clear and accepted meanings. There was no dispute that the new charter established a central government with three distinct branches and ordained that each would have certain characteristics and powers, nor was there any dispute that it also limited those national branches in various ways. Equally, there was no dispute that the Constitution confirmed the existence of the states and made them constituent elements of the new central government, and there was no dispute that it also limited the powers of those states and made federal law "supreme." The widespread acceptance of that basic institutional structure - supported by a broad cultural consensus among the nation's elite, long experience with the practice of representative government among the people, and the immense prestige of the man elected to serve as the nation's first presidentenabled the new central government to organize itself and begin operations. That bare initial achievement, James Madison believed, was by itself "a miracle." 15

At the same time, however, disagreements about the powers of those levels and branches and about their proper working relationships erupted immediately, and the earliest and most explosive raged over the disputed line between state and national authority. Over the course of the following centuries those controversies seldom flagged. Given that history of congenital disputation, the current revival of originalism and federalism provokes two paramount and related questions. ${ }^{16}$ One goes to the Constitution itself: What, in fact, was the "original" nature of the federal structure it established? The other goes to the persisting disagreement about the way that federal structure was to function: Why did Americans fight over its proper operation so immediately, so continuously, so broadly, and so fiercely? 
This inquiry seeks, and proposes, answers to those two questions. On the first, it concludes that the "original" federal structure was marked by four inherent characteristics. It was doubly blurred, fractionated, instrumental, and contingent. The claim is not that those four characteristics were parts of any original "meaning" or "understanding" but, rather, that they were built-in characteristics of the constitutional structure and that they existed independent of any intentions or understandings of the founders. On the second question, the inquiry concludes that those four characteristics made the original federal structure intrinsically elastic, dynamic, and underdetermined. Those qualities made constitutional disagreements about federalism inevitable, and they made most of those disagreements - insofar as Americans sought to settle them by reference to some "original" constitutional meaning or understanding-inherently unresolvable. Hence, immediate, continuous, broad, and fierce disputation.

The inquiry argues, then, that any claim that the "original" nature of American federalism can serve as a specifically directive norm-such as Chief Justice William Rehnquist's invocation of “the Framers' carefully crafted balance of power between the States and the National Government"17 - is simply mistaken. No such "true" or "correct" balance ever existed. ${ }^{18}$ Equally important, the inquiry also argues that, even had there been some true "original" balance, the constitutional structure the founders established was inherently incapable of maintaining it. To understand American federalism, in other words, one must consider far more than constitutional text, structural relationships, and "originalist" sources; one must also understand federalism's inherent elasticity and dynamism.

Stated so briefly, those conclusions require three points of immediate clarification. First, it is essential to distinguish between the federal "structure" and the working processes, or evolving "systems," of American federalism. The Constitution's federal structure - the existence of diverse levels and branches of government with distinctive institutional characteristics and powers - was both evident and uncontested. The way that structure was to function in practice - how the levels and branches would operate, how far their powers would reach, and how they would interact with one another-was not. The doubly blurred, fractionated, instrumental, and contingent nature of the constitutional structure, then, had its para- mount effect not on the federal structure itself but on the structure's operations, on the working processes of what came to be called the federal system. Second, the inquiry's conclusions are not based on any theory or assumption about the general "indeterminacy" of law or language. To the contrary, the inquiry assumes that words, rules, concepts, and principles may convey meanings that are fairly determinable either generally or in specific contexts. Its conclusions, then, are based not on general theories of language or meaning but on empirical evidence from the nation's history. Third, those conclusions do not purport to apply necessarily to other areas of constitutional law. The inquiry's focus is narrow and specific. It concentrates on only one aspect of the U.S. Constitution-its federal structure and its resulting federal system of government-and attempts to answer only questions about that particular constitutional issue.

Specifically, then, the inquiry suggests that the Constitution neither gave the federal structure any single proper shape as an operating system of government nor mandated any particular and timeless balance among its components. It suggests, rather, that the Constitution established a structure that accepted certain types of change as natural and desirable. It concludes, then, that there was no "original" intention, understanding, or meaning that prescribed either a single and true federal system or a single and true set of relationships among the structure's constituent parts; further, it concludes that, even had such a "true" system existed in some "original" intent or understanding, the governmental structure the founders established could not have preserved it unchanged over time.

Further, the inquiry suggests that the workings of the federal structure cannot be understood without examining the separation of powers at the national level. Although federalism and separation of powers were different concepts embodied in different institutional arrangements and subject to different sets of incentives and limitations, they were nonetheless inextricably intertwined in their operations. ${ }^{19}$ Both constitutional law and national politics were shaped by their continuous, shifting, and varied interactions. The idea of American federalism as a simple binary division between "the nation" and "the states," then, is an artificial abstraction unrelated to the actual history and operations of the nation's constitutional system.

The separation of powers vastly multiplied the complexities and uncer- 
tainties of American constitutional federalism for two readily apparent reasons. First, the existence of three separate national branches meant that the central government would sometimes be riven by internal conflicts and consequently unable to articulate and enforce consistent and unified "national" policies. The attitude of the three national branches toward the states and the federal structure would vary and often conflict, sometimes sharply and profoundly. Second, the constitutional provisions specifying the powers of the national branches were, like the provisions dividing state and national powers, imprecise and incomplete. The claim that the Constitution established an "assigned balance of responsibility and power among the three [national] branches, ${ }^{20}$ in other words, is as mistaken as the claim that the Constitution established a "carefully crafted balance" between states and nation. Thus, the inquiry argues, institutional divisions and constitutional ambiguities in the separation of national powers radically compounded the divisions and ambiguities that were inherent in the relationship between nation and states.

The inquiry argues that the Constitution did create a governmental structure with an essential and unalterable core, but it suggests that the core lay not in any "assigned" or "carefully crafted" balance but rather in a dynamic combination of three interrelated elements that allow a range of acceptable permutations. The first element was the principle of divided but interconnected and potentially "checking" powers. The second was the institutional specification of that principle along two crosscutting and internally divided dimensions, multiple individual units on the state level and separated powers on the national level. The third was the moral and political ideal that the principle of divided powers and its institutional embodiment were designed to serve, that of a free, just, and self-governing society. ${ }^{21}$

Further, the inquiry suggests that ideas and attitudes about the federal structure and its "original" form have invariably been shaped not simply by the Constitution and accepted "originalist" sources but also by the personal views of the individuals who held those ideas and attitudes. It does not deny that many individuals believed passionately in their various conceptions of the federal structure or that many also believed sincerely that their conceptions were mandated by the Constitution itself. The inquiry argues only that their conceptions could not, in fact, have come solely from those authoritative sources. The inquiry suggests, rather, that those who held such beliefs were either unable or unwilling to recognize the ways in which their personal values, interests, and assumptions shaped the particular meanings they attributed to the federal structure. ${ }^{22}$ The inquiry counsels, consequently, that all specific prescriptions allegedly derived from either the federal structure or "originalist" ideas about that structure must be evaluated not just in terms of formal constitutional arguments but also in light of the particular values and interests of those who advance them and, most important, in light of the practical implications and social consequences that the prescriptions would likely entail if accepted.

Many scholars, of course, have recognized that personal views shape interpretations of the Constitution. ${ }^{23}$ The inquiry extends that insight in two ways. First, it suggests that, with respect to American constitutional federalism, such subjectivism is inherent and unavoidable. The Constitution does not establish any single and true balance in the federal structure, and the structure itself is, in any event, too elastic, dynamic, and underdetermined to sustain any such unchanging balance. Thus, specific normative interpretations of federalism must necessarily be rooted in the personal values and interests of their advocates. Second, and consequently, the inquiry suggests that sound constitutional reasoning on federalism issues must move beyond invocations of general "principles" and "original" meanings and ground itself on specific, pragmatic, and empirically based analyses of the operations of the federal structure and the likely practical consequences involved in accepting any particular interpretation of its nature and limits. Focusing on such careful pragmatic analyses, it argues, would help cabin the inherent, if often ignored or denied, subjectivism involved in deciding federalism issues. It would force interpreters to recognize and account more fully for the interests, purposes, assumptions, and values that shape their views, and it would help channel decision making along lines more likely to achieve the substantive goals of the nation's constitutional enterprise. ${ }^{24}$

Finally, the inquiry suggests that the federal structure is best understood not as a freestanding institutional construct, or as a simple embodiment of an "original" architectural blueprint, but as an integral part of the collective constitutional enterprise of the American people, the concerted intergenerational effort to realize and sustain the ideal of a free, just, and self- 
governing society. The continuing legitimacy of the nation's constitutional government, after all, derives not from any original social contract capable of binding later generations and providing them with specific directions. Rather, it derives from other, and far more compelling, sources: the continuing popular judgment that the Constitution embodies both political and moral wisdom and the inspiring but sobering fact that wethe current people of the United States - are the inheritors and beneficiaries of the work of successive generations that created, defended, and interpreted the Constitution in their collective efforts to secure the "Blessings of Liberty" for themselves and their posterity, that is, for us and for our own posterity. ${ }^{25}$

In reaching and explaining its conclusions, the inquiry proceeds in three parts. The first, comprising Chapters 2 through 5 , examines the four intrinsic characteristics of the "original" federal structure. The second, comprising Chapters 6 through 9, explores some of the consequential dynamics that resulted from those original characteristics. Finally, the third part, Chapter 10, reflects on the more general significance of the inquiry's analysis and conclusions.

In Part I, Chapter 2 considers the structure's intrinsically doubly blurred nature, the fact that the Constitution divided power between national and state governments in a manner that was both ambivalent and ambiguous. The division was ambivalent because the Constitution gave the two levels of government overlapping powers and responsibilities in conducting republican government and protecting republican values. It thereby ensured that they would exist in tension and that, on disputed issues, both could claim to stand for the nation's highest moral and political principles. The division was ambiguous because the Constitution failed to identify the boundaries between the two levels with clarity and completeness, thereby ensuring that each would frequently have grounds to dispute the other's authority. From the beginning, then, the two levels were placed in tension with neither their realms nor their relationships adequately prescribed.

Chapter 3 explores the structure's fractionated nature. The Constitution did not create a simple binary structure but rather one that was manysided and multi-linked. It divided the national side into three parts, and for good measure bifurcated one of those three parts into two differently con- stituted and differently empowered halves. Similarly, the Constitution embraced an even more fragmented division on the state side, encompassing many separate entities, providing for their steady multiplication over time, and allowing each to subdivide into as many local governing units as it chose. Thus, the Constitution created a structure that loosely and flexibly linked three separate and quite different national branches - one of which was itself divided internally - with an expanding multitude of diverse and often conflicting state and local government units. It was a complexly fractionated structure that proved inherently dynamic, generating over time a virtually infinite number of varied and shifting geographical and institutional alliances, all of which crosscut the Constitution's formal binary divide between "national" and "state" governments. That fractionated structure gave birth to a kaleidoscopic interstate politics that further blurred the boundaries of authority in the federal structure by pressing new and shifting meanings onto its doubly blurred constitutional lines and by preventing either "the states" or "the nation" from acting consistently and cohesively as unified entities to maintain any timeless division between their powers.

Chapter 4 examines the intrinsically instrumentalist nature of the federal structure. The founders assumed that ambition and self-interest drove "factions" to exploit government and that mere "parchment" lines would be insufficient to block factional aggrandizements. Only purposive human actions could check other purposive human actions. Consequently, they designed the federal structure as an instrument to control factions by dividing power among diverse levels and branches capable of "checking" one another's abuses and aggrandizements. Providing the framework, components, and incentives for such purposive and responsive actions, then, the federal structure was inherently an instrument of human goals and ambitions. Its doubly blurred lines, however, did not adequately specify the conditions under which one level or branch was properly to "check" another, and it consequently allowed factions ample leeway in justifying their efforts to exploit the power of whichever governmental components they happened to influence or control. "Checking," then, quickly proved to be but one of many possible forms of response open to the structure's components. Others included acquiescing, deflecting, adapting, facilitating, exploiting, and extending. That wide range of possible responses 
compounded the structure's inherent elasticity and dynamism; and, as those who controlled its various components acted and responded in diverse ways, they created shifting sets of institutional interrelationships that altered the powers of the various levels and branches and, in the process, reshaped the operations of the federal structure.

Chapter 5 considers the structure's contingent nature, the fact that its lines of division were dependent on constitutional provisions that incorporated numerous principles of change. The chapter identifies the ways in which the Constitution mandated some changes, authorized others, and invited yet more. Thus, as the nation and its surrounding world environment evolved, some changes were compelled by constitutional mandates, others flowed from constitutionally authorized choices, and still others resulted from the new significance that changes in the world environment gave to many constitutional provisions. As those varied changes occurred, new matrices of pressures, conditions, and assumptions remolded the federal structure. Whether the Constitution's provisions mandated, authorized, or merely invited change, they combined to make the federal structure inherently malleable and adaptive.

Those four characteristics, the section concludes, explain the dynamic and underdetermined nature of American federalism. They created a governing structure that was marked by far too many ambiguities and elasticities to define any single and "correct" balance between states and nation. It was a structure composed of far too many dynamic and interconnecting parts, all of which were themselves both mutable and manipulable, to sustain any particular and timeless balance.

Part II considers some of the specific consequences that those four characteristics brought to the federal structure and the nation's constitutional enterprise. Chapter 6 examines the volatile and pragmatic interstate politics that grew out of the structure's fractionated nature. Although political organizations and interests worked within the Constitution's binary division, they also exploited it ruthlessly and methodically. As ever-expanding numbers and varieties of interests clashed in their efforts to exploit the different levels and branches of government, they generated ever-multiplying and ever-shifting sets of interstate alliances and counteralliances that continuously stretched and reshaped the doubly blurred lines between "national" and "state" authority. Their practices nourished ideas, interests, coalitions, expectations, and interconnections that overflowed the Constitution's binary categorization and forged a kaleidoscopic interstate politics whose pressures repeatedly remolded the workings of the federal structure and shifted its lines of operative authority.

Chapter 7 focuses on the federal structure's institutional components themselves, especially its three national branches. The chapter examines the ways in which the structure's intrinsic characteristics enabled and encouraged those institutions to reshape themselves as they adapted to changes in the world around them, including changes that were occurring in the other levels and branches of government. Exercising broad and often undefined powers, and enjoying substantial discretion over their own internal structure and operations, the national branches expanded their distinctive powers in divergent and sometimes conflicting ways, while each evolved into a distinctive and complex set of interlocking - and quite imperfectly integrated-bureaucracies. Over the years they repeatedly reshaped their actions and readjusted their relationships, and their effortssometimes separately and sometimes in combination-altered the operations of the individual branches and stretched the boundaries of their powers. Indeed, in the early twenty-first century not one of the federal branches remained the same in size, operation, organization, significance, or scope of authority as it had been in the nineteenth century or even much of the twentieth century, let alone as it had been "originally" in 1789 .

Chapter 8 examines one of the Constitution's paramount ambiguities, its failure to specify a mechanism for enforcing divisions between national and state power. It explores the varied theories that the founding generation launched, the intensifying disputes that only a Civil War could begin to resolve, and the subsequent debates that increasingly focused on whether the U.S. Supreme Court could and should enforce the constitutional division between state and national power. Questions about the Court's proper role, like many other questions about the federal structure, went unresolved by the founders. The resulting uncertainties led to an unending train of disputes that could be settled by neither the language of the Constitution nor the "original" views of the founders but only by the politics, ideologies, and practicalities of their respective times.

Chapter 9 moves to a broader level and considers some of the ways in 
which general ideas about the federal structure and the Constitution changed over the centuries. It focuses, in particular, on changes in ideas about the "values" and "nature" of federalism itself, and it suggests that constitutional commentators have consistently been unable to transcend the uncertainties and dynamics that were rooted in the federal structure's four inherent characteristics. The chapter concludes that normative theories founded on interpretations of the "values" and "nature" of federalism reflected rather than resolved those uncertainties and dynamics and that, as those underlying ideas and assumptions evolved, both the understanding and operation of the federal structure evolved as well.

Finally, Part III, Chapter 10, attempts to synthesize the lessons to be drawn from a recognition of the elastic, dynamic, and underdetermined nature of the federal structure. It offers no specific normative theory of federalism and suggests that the Constitution neither mandates nor requires any such specific theory. It closes not in resignation or despair, however, but in hope and commitment. If the inquiry's conclusions are sound, the chapter suggests, it does not mean that the nation's constitutional enterprise lacks either understandable norms or, in at least some of its provisions, relatively clear and guiding rules and principles. It means only that the Constitution itself, with or without the aid of "originalist" sources, could not and did not provide specifically directive norms capable of resolving the contested issues of federalism that divided Americans after 1787. It also means that they cannot do so in the future. That ever-present and ineluctable burden, the inquiry concludes, rests on each succeeding generation of Americans, the very posterity on whose behalf the founders-and, of course, the succeeding generations who broadened the concept of national citizenship to include those originally excluded - sought to act. 